\title{
Mikrobaszám és enzimaktivitás változása szárazbabfajták (Phaseolus vulgaris L.) rizoszférájában sóterhelés hatására
}

\author{
${ }^{1}$ KHALIF A. ABDOUSSALAM, ${ }^{1}$ ABDORHIM HAMED, ${ }^{1}$ BAYOUMI HAMUDA E. \\ A. F. HOSAM, ${ }^{2}$ OLDAL BÁLINT és ${ }^{1}$ KECSKÉS MIHÁLY \\ ${ }^{1}$ Szent István Egyetem, Környezettudományi Doktori Iskola, Gödöllő-Budapest és \\ ${ }^{2}$ MTA Talajtani és Agrokémiai Kutatóintézet, Budapest
}

A talajban előforduló mikroorganizmusok által termelt enzimek a tápanyagkörforgalomban lejátszódó folyamatokat katalizálják, ezért minőségüktől és menynyiségüktől függően alkalmasak a különböző mikrobiális aktivitások becslésére is (MIKANOVÁ et al., 2001). Az enzimek között a foszfatáz növények táplálásában betöltött szerepe közismert, míg a fehérjék proteázok általi hidrolízise a talajban lejátszódó szerves-N-körforgalom egyik fontos lépése. Az állati, növényi és mikrobiális anyagok bomlása során az amidok hidrolízisét az ureáz és az amidáz végzi (DASH \& PANDA, 2001), a $\beta$-glükozidáz pedig a cellulóz glükózzá történő teljes lebontásának fontos mediátora. A dehidrogenáz és a kataláz a redoxfolyamatok általános katalizátorai, mennyiségük ezért - ahogy a felsorolt többi enzimé - szintén a talaj mikrobiális aktivitásának kifejezője (TABATABAI, 1982; ANTAL \& ANTON, 1986; ANTON et al., 1994).

Az ozmolaritás viszont a mikroorganizmusok élettevékenységét meghatározó egyik kulcsfontosságú környezeti tényező, amely így közvetlenül befolyásolja a talaj termékenységét. A növények rizoszférájának mikrobiális összetétele tehát direkt összefüggésbe hozható a talajállapottal (BIRÓ et al., 2002). A jellemző mikrobák között a környezeti tényezőkkel szemben toleráns, így pl. sótürő fluoreszkáló Pseudomonas baktériumok már korábban is leírt (BIRÓ et al., 1998) jó túlélő képessége és erős gyökérkolonizáló aktivitása eredményesen támogathatja a káros környezeti stressztényezők elviselését, ennél fogva kedvező a magasabb rendü növények környezeti adaptációja tekintetében is.

Előző vizsgálataink során leírtuk (KHALIF et al., 2004), hogy a talajhoz különböző mennyiségben adagolt $\mathrm{NaCl}$ hatására - fehér lóhere tesztnövényt alkalmazva miként változik meg az egyes enzimek aktivitása és a fent jelzett „fluorescensputida" típusú Pseudomonas baktériumok csíraszáma a rizoszférában, valamint öszszefoglaltuk a talaj sótartalmának e mikrobaközösség sürüségére és az enzimaktivitásokra gyakorolt hatásával kapcsolatos addigi legfontosabb megállapításokat. Jelen munkánkban a korábbi analógiájára, de bab jelzőnövénnyel végzett kísérleteink eredményeit adjuk közre.

Postai cím: HOSAM E. A. F. BAYOUMI HAMUDA, Szent István Egyetem Környezettudományi Doktori Iskola, 1111 Budapest, Budafoki út 59. E-mail: titkar@mpv.ph.hu 


\section{Anyag és módszer}

Kisérleti elrendezés. - Vizsgálatainkban Gödöllő város környékéről (Gödöllőidombság) származó Ramann-féle barna erdőtalajt (Dystri-Chromic Cambisol; WRB, 1998) használtunk, melynek humusztartalma 1,2\%, kémhatása $\mathrm{pH}(\mathrm{KCl}) 4,67$ volt. A talaj sótartalmának növelésére 99,5\%-os tisztaságú NaCl-ot alkalmaztunk 0 , $0,1,0,2,0,4$, és 0,8 tömegszázalék $(\mathrm{m} / \mathrm{m} \%)$ arányban száraz talajra vonatkoztatva.

A vizsgálatot három, Magyarország eltérö ökológiai adottságú területein biztonsággal termeszthető, azonos tenyészidejü étkezési szárazbabfajtával (Phaseolus vulgaris L.): Diana (Pinto típusú tarkabab, mozaikvírusokkal és baktériumos hüvelyfoltossággal szemben ellenálló); Albamax (nagy szemü fehérbab, szárazságtürô, a betegségekkel szemben ellenálló); és Perle (konzervipari célra is alkalmas gyöngybab, jó vízfelvevő képességü, de fenésedéssel szemben fogékony) - végeztük el. Egyenként 5 szem felületén sterilizált bab magot vetettünk 2 1-es, 2,5 kg fentiek szerint kezelt talajt tartalmazó cserépedényekbe úgy, hogy a magokat $2 \mathrm{~cm}$ vastag talajréteggel takartuk be. Két hét elteltével a magból kikelt csíranövényeket 3 tőre ritkítottuk, és a továbbiakban a cserepeket szükség szerint öntöztük steril, desztillált vízzel. A növényeket üvegházban, természetes fényen (14 órás fotóperiódusnál), $23 \pm 2{ }^{\circ} \mathrm{C}$-on neveltük 50 napig, majd a relatív száraz tömeget 50 napig tartó nevelést követően határoztuk meg $\left(75^{\circ} \mathrm{C}\right.$ hőmérsékleten, szárítószekrényben, tömegállandóságig szárítva) a kontrollhoz képest.

Talaj-mikroorganizmusok elöfordulása. - A mikroorganizmusok rizoszférában való előfordulásának felmérése során a növényeket gyökerestől kivettük a talajból, és folyó csapvízzel tisztára mostuk a rátapadó talajrészecskék eltávolítása céljából. Ezt követően a gyökereket apróra vágtuk, majd steril, 0,85\%-os sótartalmú fiziológiás sóoldatban, dörzsmozsárban homogenizáltuk. A gyökerekből $1 \mathrm{~g}$ mennyiséget felaprítottunk, majd $9 \mathrm{ml}$ fiziológiás sóoldattal maceráltunk. A szuszpenzióból steril csapvízzel hígítási sort készítettünk. A rizoszférában előforduló összes aerob mikrobaszámot, az aerob spóraképzők, az aktinomiceták és a mikroszkopikus gombák számát szelektív táplemezek felhasználásával határoztuk meg SzEGI (1979) módszere szerint. Ennek során a mintákból 0,1-0,1 ml-nyi mennyiségeket szélesztettünk King-B, Pseudosel, Nutrient, tripton-glükóz-élesztőkivonat, Martin, malátakivonat, Jensen, valamint Küster-Williams szilárd táptalajokra. A különböző táptalajokon történt tenyésztés során Pseudomonas, Bacillus faj-reprezentánsokat, ill. spóraképző baktériumokat, mikroszkopikus gombákat (pl. élesztők és Trichoderma sp.), valamint aktinomicetákat is izoláltunk. Az agarlemezeket a mikrobák típusának megfelelően 28,30 , ill. $37^{\circ} \mathrm{C}$-on inkubáltuk 2-7 napig.

A fluoreszkáló Pseudomonasok kimutatása. - A feltárt gyökérmintákból steril fiziológiás sóoldattal hígítási sort készítettünk. Mintánként 0,1 ml-t King-B (KING et al., 1954) és Pseudosel agar táptalajra szélesztettünk fluoreszkáló Pseudomonas törzsek izolálása céljából. A táptalajokhoz cikloheximidet $\left(100 \mu \mathrm{g} \cdot \mathrm{ml}^{-1}\right)$ és benomilt $\left(30 \mu \mathrm{g} \cdot \mathrm{ml}^{-1}\right)$ adtunk a gombák elszaporodásának megakadályozása céljából. A táplemezeket $30^{\circ} \mathrm{C}$-on inkubáltuk, majd két nap után megszámoltuk a kinőtt telepeket. 
Ezekből random módon izolálást végeztünk King-B agarra, hígítással és szilárd táptalajon történő szélesztéssel megtisztítottuk, majd $4{ }^{\circ} \mathrm{C}$-on tároltuk a későbbi vizsgálatokig. Az izolált fluoreszkáló Pseudomonasok meghatározása a BBL Crystal $^{\mathrm{TM}}$ identifikációs kittel történt. A rizoszférában élő mikroorganizmusokat NAUTIYAL és DiON (1990) módszerével jellemeztük.

Az enzimaktivitások mérése. - A dehidrogenázaktivitás méréséhez $1 \mathrm{~g}$ talajmintát $0,2 \mathrm{ml}$ 4\%-os 2-P-jód-fenil-3-P-nitrofenil-5-fenil-tetrazólium kloridba (INT) áztattuk $22{ }^{\circ} \mathrm{C}$-on, fénytől védve. A talajban keletkezett jódnitrotetrazólium formazánt (INTF) etilén-klorid és aceton 1:1,5 arányú elegyével extraháltuk, koncentrációját spektrofotométeren mértük meg $490 \mathrm{~nm}$ hullámhosszon (GARCíA et al., 1993). Az aktivitást $\mu \mathrm{g} \cdot \mathrm{g}^{-1}$ mértékegységben fejeztük ki, a keletkezett INTF menynyiségét a száraz talaj egy grammjára vonatkoztatva.

A katalázaktivitást a talajmintákban $\mathrm{H}_{2} \mathrm{O}_{2}$ hozzáadását követően permanganometriás eljárással mértük meg (TABATABAI \& BREMNER, 1970). Az aktivitást $\mu \mathrm{mol} \cdot \mathrm{g}^{-1} \cdot \mathrm{min}^{-1}$ mértékegységben fejeztük ki, az egy perc alatt fogyott $\mathrm{O}_{2}$ mennyiségét a száraz talaj egy grammjára vonatkoztatva.

Az ureázaktivitás meghatározásához $2 \mathrm{ml}$ foszfát-pufferoldatot $(\mathrm{pH}=7)$ és 0,5 $\mathrm{ml}$ 6,4\%-os karbamid-oldatot adtunk $0,5 \mathrm{~g}$ talajhoz, majd $30{ }^{\circ} \mathrm{C}$-on inkubáltuk 90 percig. Ezután az elegyet steril desztillált vízzel $10 \mathrm{ml}$-re hígítottuk, majd $\mathrm{NH}_{4}{ }^{+}-$ szelektív elektróddal megmértük a $0,1 \mathrm{ml} 10 \mathrm{M}$-os $\mathrm{NaOH}$-dal felszabadított $\mathrm{NH}_{4}^{+}$koncentrációt. Minden talajmintával kontrollvizsgálatot is végeztünk, karbamid hozzáadása nélkül (NANNIPIERI et al., 1980). Az enzimaktivitást a felszabadult $\mathrm{NH}_{4}{ }^{+}-\mathrm{N}$ mennyiségével $\left(\mu \mathrm{mol} \cdot \mathrm{g}^{-1} \cdot \mathrm{h}^{-1}\right)$ mértük.

A proteázaktivitás mérése során $2 \mathrm{ml}$ foszfát-pufferoldatot $(\mathrm{pH}=7)$ és $0,5 \mathrm{ml}$ $0,05 M \mathrm{~N}-\alpha$-benzoil-L-arginamid szubsztrátumot adtunk $0,5 \mathrm{~g}$ talajmintához, majd $37^{\circ} \mathrm{C}$-on 90 percig inkubáltuk. Ezután az elegyet 10 ml-re hígítottuk steril desztillált vízzel. A felszabadult $\mathrm{NH}_{4}{ }^{+}$koncentrációját az ureáz meghatározására alkalmazott módon mértük (NANNIPIERI et al., 1980). Az aktivitást a felszabadult $\mathrm{NH}_{4}{ }^{+}-\mathrm{N}$ $\left(\mu \mathrm{mol} \cdot \mathrm{g}^{-1} \cdot \mathrm{h}^{-1}\right.$; száraz talajra vonatkoztatva) mennyiségével írtuk le.

A foszfatázaktivitást TABATABAI és BREMNER (1969) módszere szerint határoztuk meg, $\mathrm{s}$ a felszabadult $p$-nitrofenol mennyiségével $\left(\mu \mathrm{mol}\right.$ PNP·g száraz talaj $\left.{ }^{-1} \cdot \mathrm{h}^{-1}\right)$ jellemeztük.

A $\beta$-glükozidázaktivitás mérése a MASCIANDARO és munkatársai (1994) által leírt módszerrel történt. Az eredményt a felszabadult $p$-nitrofenol (PNP) mennyiségével $\left(\mu \mathrm{mol} \cdot \mathrm{g}^{-1} \cdot \mathrm{h}^{-1}\right)$ fejeztük ki, szintén száraz talajra vonatkoztatva.

Statisztikai analizis. - A kísérleteket teljes randomizált blokk elrendezésben, három ismétléssel végeztük. A kezelések közötti statisztikai különbségek meghatározásához egytényezős varianciaanalízist (Single Factor ANOVA) használtunk. A szignifikáns differenciát $(\mathrm{SzD}) \mathrm{P} \leq 0,05$ szinten állapítottuk meg. 


\section{Eredmények}

Vizsgálatunk során a különböző babfajták rizoszférájában az egyes jellemző mikrobacsoportok száma az alkalmazott sókoncentrációtól függően, de fajtánként is változatosságot mutatott (1. táblázat). Az összes baktériumszám a koncentráció enyhe emelkedésével $(0,2 \mathrm{~m} / \mathrm{m} \%$-ig) párhuzamosan nőtt, de ennél nagyobb dózisok

\section{1. táblázat}

Mikrobaszámok változása a különböző koncentrációjú NaCl-oldattal (m/m\%) kezelt babfajták (Phaesolus vulgaris L.) rizoszférájában

\begin{tabular}{|c|l|c|c|c|c|c|c|}
\hline \multirow{2}{*}{$\begin{array}{c}(1) \\
\text { Mikroba-csoportok }\end{array}$} & Babfajta & 0 & 0,1 & 0,2 & 0,4 & 0,8 & SzD \\
\cline { 3 - 7 } & Diana & 89 & $131^{*}$ & $154^{*}$ & 91 & $37^{*}$ & 28,08 \\
a) Baktériumok & Albamax & 88 & $195^{*}$ & $143^{*}$ & 77 & 54 & 35,71 \\
$\left(10^{6}\right)$ & Perle & 82 & $112^{*}$ & 66 & $45^{*}$ & $23^{*}$ & 21,37 \\
\hline b) Aerob spóra- & Diana & 1,9 & $3,3^{*}$ & $4,6^{*}$ & $6,6^{*}$ & $8,9^{*}$ & 1,39 \\
képző baktéri- & Albamax & 2,7 & 3,9 & $4,4^{*}$ & $7,2^{*}$ & $9,8^{*}$ & 1,68 \\
umok $\left(10^{3}\right)$ & Perle & 1,2 & 2,3 & $3,3^{*}$ & $4,1^{*}$ & $6,5^{*}$ & 1,25 \\
\hline \multirow{2}{*}{ c) Aktinomiceták } & Diana & 1,6 & $2,4^{*}$ & $4,1^{*}$ & $3,3^{*}$ & 1,4 & 0,71 \\
$\left(10^{3}\right)$ & Albamax & 1,7 & $2,7^{*}$ & $3,3^{*}$ & $2,9^{*}$ & 1,6 & 0,47 \\
& Perle & 1,4 & $1,9^{*}$ & $2,2^{*}$ & $1,7^{*}$ & 1,2 & 0,25 \\
\hline \multirow{3}{*}{ d) Gombák $\left(10^{4}\right)$} & Diana & 15,1 & $18,7^{*}$ & $23,1^{*}$ & 17,1 & $9,5^{*}$ & 3,12 \\
& Albamax & 12,3 & $19,1^{*}$ & $26,3^{*}$ & 15,6 & $7,1^{*}$ & 4,52 \\
& Perle & 11,9 & $16,3^{*}$ & $24,2^{*}$ & $20,1^{*}$ & $15,7^{*}$ & 2,93 \\
\hline
\end{tabular}

Megjegyzés: A *-gal jelölt érték szignifikáns eltérést mutat a kontrollnövényeknél mért értékekhez viszonyítva $(\mathrm{P} \leq 0,05)$

mellett - a barna- és a gyöngybab esetében szignifikánsan is - csökkent. Az aerob spóraképző baktériumok száma viszont a sótartalom növekedésével egyre gyarapodott, minden fajtánál szignifikáns mértékben. Az aktinomiceták száma az összbaktériumszámtól eltérően még a $0,4 \mathrm{~m} / \mathrm{m} \%$-os koncentrációtartományban is igazolhatóan nagyobb volt a kontrollnál, de a legnagyobb dózis esetén sem csökkent szignifikáns mértékben. A gombák viselkedése az aerob spóraképző baktériumokéhoz volt hasonló. Ez arra utal, hogy erösebb sóstressz esetében csak a megfelelö védekezési mechanizmussal rendelkező mikroorganizmusok maradnak meg, illetve ekkor már csupán a tokot, vagy spórát képzők inaktív formák (pl. Bacillus sp., gombák) tenyészthetők ki - az aktív metabolizmus a talajban nagyon lecsökken, illetve meg is szünhet.

Az egyes mikrobacsoportok sóstressz hatása alatt regisztrált előfordulása a barna- és a fehérbab rizoszférájában hasonló mértékü volt, míg a gyöngybab gyökerein rendre kisebb mikrobaszámokat találtunk. Ennek oka valószínüleg arra vezethetö vissza, hogy a gyöngybab sóstressz esetén eltérő összetételü gyökér-exszudátumokat választ ki, azaz a növény fiziológiai állapota a másik két fajtához képest na- 


\section{2. táblázat}

Különböző babfajták (Phaesolus vulgaris L.) rizoszférájának baktérium-populációja gödöllöi Ramann-féle barna erdőtalajon, 50 nap üvegházi termesztés után

\begin{tabular}{|l|c|c|c|}
\hline \multirow{2}{*}{$\begin{array}{c}\text { Domináns baktériumok populáció- } \\
\text { jának összetétele a rizoszférában }\end{array}$} & \multicolumn{3}{|c|}{ Részarány (\%) } \\
\cline { 2 - 4 } & Diana & Albamax & Perle \\
\hline \multirow{2}{*}{ a) Gram negatív } & 65,5 & 71,2 & 61,3 \\
b) Pálcika alakú & 86,7 & 85,9 & 83,1 \\
c) Fluoreszkáló Pseudomonasok & 41,2 & 43,7 & 32,5 \\
P. fluorescens & 37,2 & 46,3 & 31,2 \\
P. putida & 29,2 & 21,2 & 22,9 \\
P. fulva. & 24,1 & 27,1 & 19,5 \\
Pseudomonas sp & 9,5 & 5,4 & 26,4 \\
d) Gram pozitív & 34,6 & 28,8 & 38,7 \\
b) Pálcika alakú & 71,9 & 78,7 & 72,5 \\
Bacillus sp. & 41,1 & 42,3 & 39,2 \\
\hline
\end{tabular}

gyobb mértékben változik meg. Az egyes fajták ökofiziológiai vizsgálata ezért további - termőhely-specifikus - különbségekre is választ adhat.

A továbbiakban a baktériumok előfordulását vizsgálva azt az eredményt kaptuk, hogy a Gram negatív szervezetek domináltak a bab rizoszférájában (80\%), s közöttük is két Pseudomonas faj uralkodott (2. táblázat). A teljes fluoreszkáló Pseudomonas populáció $40,1 \%$-át a $P$. fluorescens, míg 23,8\%-át a $P$. putida tette ki.

A talaj $\mathrm{NaCl}$-oldattal történő kezelése jelentős változásokat eredményezett a fluoreszkáló Pseudomonas populációban (3. táblázat). A NaCl-koncentráció növelésével számuk jelentősen növekedett a gyökérfelszínen egészen a 0,4\%-os NaClkoncentrációig. A legmagasabb értéket $0,4 \%$-os koncentráció mellett mértük

\section{3. táblázat}

Különböző babfajták (Phaesolus vulgaris L.) rizoszférájának fluoreszkáló Pseudomonas populációja, növekvő sókoncentráció hatására

\begin{tabular}{|c|c|c|c|}
\hline \multirow{2}{*}{$\begin{array}{c}(1) \\
\text { NaCl-kezelés } \\
(\mathrm{m} / \mathrm{m} \%)\end{array}$} & \multicolumn{3}{|c|}{$\begin{array}{c}(2) \\
\left(\mathrm{CFU} \times 10^{4}\right)\end{array}$} \\
\cline { 2 - 4 } & Fluoreszkáló Pseudomonas-ok mennyisége \\
\hline 0 & 1,2 & 1,6 & Plbamax \\
0,1 & 1,5 & $2,3^{*}$ & 1,1 \\
0,2 & $1,9^{*}$ & $2,7^{*}$ & 1,3 \\
0,4 & $2,1^{*}$ & $3,1^{*}$ & $2,3^{*}$ \\
0,8 & $1,7^{*}$ & $2,6^{*}$ & $1,8^{*}$ \\
a) SzD $(\mathrm{P} \leq 0,05)$ & 0,35 & 0,56 & 0,47 \\
\hline
\end{tabular}

Megjegyzés: A *-gal jelölt érték szignifikáns eltérést mutat a kontrollnövényeknél mért értékekhez viszonyítva $(\mathrm{P} \leq 0,05)$ 
$\left(3,1 \times 10^{4} \mathrm{CFU} \mathrm{g}^{-1}\right.$ talaj), de a vizsgált koncentrációk közül a $0,8 \%$-os sem gátolta a baktériumok szaporodását.

A különböző NaCl-oldatok koncentrációjának a vizsgált babfajták gümöképzésére gyakorolt hatását értékelve azt találtuk, hogy a 0,1 és $0,2 \mathrm{~m} / \mathrm{m} \%$-os töménységű sóoldatok alkalmazásakor a gümőszám a kontrollhoz képest számottevően emelkedett, mindazonáltal ez a különbség statisztikailag nem volt igazolható. A 0,4 $\mathrm{m} / \mathrm{m} \%$-os dózis jól észrevehető csökkenést okozott a gümők számában a kontrollhoz képest, a barna- és a gyöngybab esetében ez szignifikánsnak bizonyult, míg a $0,8 \mathrm{~m} / \mathrm{m} \%$ sóoldatos kezelés során nem találtunk gümöket a tesztnövények gyökerén.

Az egyes babfajtákat összehasonlítva kitünik, hogy a fehérbab gümőképzése volt a legintenzívebb (4. táblázat), ill. ez a fajta hozta a legnagyobb zöldtömeget is (5. táblázat). Ennek alapján a fajták közötti egyedi fiziológiai különbségek tekintetbe vételével a fehérbab a leginkább toleráns a sóstresszel szemben.

A rizoszférában mért enzimaktivitásokra vonatkozó adatokat a 6. táblázat foglalja össze. A dehidrogenáz a rizoszférában található mikroorganizmusok metabolikus

\section{4. táblázat}

A gyökérgümők számában bekövetkező változás a különböző babfajták (Phaseolus vulgaris L.) rizoszférájában, növekvő sókoncentráció hatására

\begin{tabular}{|c|c|c|c|}
\hline \multirow{2}{*}{ NaCl-kezelés $(\mathrm{m} / \mathrm{m} \%)$} & \multicolumn{3}{|c|}{ Gyökérgümök mennyisége $(\mathrm{db})$} \\
\cline { 2 - 4 } & Diana & Albamax & Perle \\
\hline 0 & 37 & 45 & 39 \\
0,1 & 46 & 67 & 51 \\
0,2 & 39 & 62 & 43 \\
0,4 & 12 & 23 & 9 \\
0,8 & 0 & 0 & 0 \\
a) SzD $(\mathrm{P} \leq 0,05)$ & 19,1 & 24,8 & 21,4 \\
\hline
\end{tabular}

5. táblázat

A növények relatív száraztömegének változása a különbözö babfajták (Phaseolus vulgaris L.) esetében, növekvő sókoncentráció hatására

\begin{tabular}{|c|c|c|c|}
\hline \multirow{2}{*}{$\begin{array}{c}(1) \\
\mathrm{NaCl}-k e z e l e ́ s \\
(\mathrm{~m} / \mathrm{m} \%)\end{array}$} & \multicolumn{3}{|c|}{$\begin{array}{l}\text { (2) } \\
\text { Relatív száraztömeg (kontroll \%-a) }\end{array}$} \\
\hline & Diana & Albamax & Perle \\
\hline 0,1 & 101 & $148^{*}$ & $158^{*}$ \\
\hline 0,2 & $146^{*}$ & $153^{*}$ & $206^{*}$ \\
\hline 0,4 & $63^{*}$ & 99 & 98 \\
\hline 0,8 & $26^{*}$ & $46^{*}$ & $53 *$ \\
\hline a) $\mathrm{SzD}(\mathrm{P} \leq 0,05)$ & 27,13 & 26,43 & 38,04 \\
\hline
\end{tabular}

Megjegyzés: A *-gal jelölt érték szignifikáns eltérést mutat a kontrollnövényeknél mért értékekhez viszonyítva $(\mathrm{P} \leq 0,05)$ 
tevékenységét jelzi, a kataláz pedig a talajban élő aerob mikroorganizmusok számára utal. A kezelt talajban a megemelkedett sótartalom nem befolyásolta hátrányosan a mikroorganizmusok metabolikus tevékenységét. Így magasabb NaCl-koncentráció értékeknél $(0,2-0,4 \%)$ fokozott enzimaktivitásokat figyeltünk meg, a legnagyobb

$$
\text { 6. táblázat }
$$

A talaj NaCl-oldattal történő kezelésének a különböző enzimek aktivitására kifejtett hatása a különböző babfajták (Phaseolus vulgaris) rizoszférájában

\begin{tabular}{|c|c|c|c|c|c|c|c|}
\hline \multirow{2}{*}{$\begin{array}{c}(1) \\
\text { Enzimek és mér- } \\
\text { tékegységeik } \\
\left(\mathrm{g}^{-1} \text { talaj }\right)\end{array}$} & \multirow[t]{2}{*}{$\stackrel{(2)}{\text { Babfajták }}$} & \multicolumn{6}{|c|}{$\begin{array}{l}\text { (3) } \\
\text { Enzimaktivitás különböző } \mathrm{NaCl}-(\mathrm{m} / \mathrm{m} \%) \\
\text { koncentrációknál (három érték átlaga) }\end{array}$} \\
\hline & & 0 & 0,1 & 0,2 & 0,4 & 0,8 & SzD \\
\hline \multirow{3}{*}{$\begin{array}{l}\text { a) Dehidrogenáz } \\
\mu \mathrm{g} \text { INTF }\end{array}$} & Diana & 102 & $156^{*}$ & $212 *$ & $131^{*}$ & 83 & 28,56 \\
\hline & Albamax & 96 & $183^{*}$ & $194 *$ & 117 & 90 & 30,75 \\
\hline & Perle & 88 & $123^{*}$ & $104 *$ & 93 & $71 *$ & 12,09 \\
\hline \multirow{3}{*}{$\begin{array}{l}\text { b) Kataláz } \\
\mu \mathrm{mol} \mathrm{O} \cdot \min ^{-1}\end{array}$} & Diana & 2,1 & $2,9^{*}$ & $3,4^{*}$ & $2,7 *$ & 1,8 & 0,39 \\
\hline & Albamax & 1,9 & $2,5^{*}$ & $2,7^{*}$ & 2,1 & $1,4^{*}$ & 0,32 \\
\hline & Perle & 1,7 & $2,2^{*}$ & $2,4^{*}$ & 1,9 & $1,3^{*}$ & 0,27 \\
\hline \multirow{3}{*}{$\begin{array}{l}\text { c) Proteáz } \\
\mu \mathrm{mol} \mathrm{NH} \cdot \mathrm{NH}^{-1}\end{array}$} & Diana & 1,8 & $2,7^{*}$ & $2,9^{*}$ & 2,1 & $1,4^{*}$ & 0,39 \\
\hline & Albamax & 1,5 & $1,9^{*}$ & $2,1^{*}$ & 1,7 & $1,1^{*}$ & 0,24 \\
\hline & Perle & 1,4 & 1,5 & $2,1^{*}$ & $1,9 *$ & $1,1^{*}$ & 0,25 \\
\hline \multirow{3}{*}{$\begin{array}{l}\text { d) Ureáz } \\
\mu \mathrm{mol} \mathrm{NH} \cdot \mathrm{h}^{-1}\end{array}$} & Diana & 0,5 & $1,9^{*}$ & $2,7^{*}$ & $2,3^{*}$ & 1,3 & 0,36 \\
\hline & Albamax & 1,3 & 1,6 & $2,5^{*}$ & $2,1 *$ & 1,1 & 0,36 \\
\hline & Perle & 1,2 & $1,7^{*}$ & $2,7^{*}$ & $1,7 *$ & 0,9 & 0,34 \\
\hline \multirow{3}{*}{$\begin{array}{l}\text { e) Foszfatáz } \\
\mu \mathrm{mol} \text { PNP.h }{ }^{-1}\end{array}$} & Diana & 124 & 112 & $110^{*}$ & $83 *$ & $71 *$ & 13,83 \\
\hline & Albamax & 120 & 108 & $100 *$ & $74 *$ & $63^{*}$ & 14,89 \\
\hline & Perle & 107 & $95^{*}$ & $90^{*}$ & $81 *$ & $69 *$ & 8,98 \\
\hline \multirow{3}{*}{ 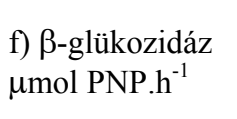 } & Diana & 214 & 198 & $173^{*}$ & $151^{*}$ & $133^{*}$ & 20,73 \\
\hline & Albamax & 201 & $182^{*}$ & $163^{*}$ & $141^{*}$ & $121 *$ & 18,91 \\
\hline & Perle & 187 & $150 *$ & $141 *$ & $123^{*}$ & $103 *$ & 19,71 \\
\hline
\end{tabular}

Megjegyzés: A *-gal jelölt érték szignifikáns eltérést mutat a kontrollnövényeknél mért értékekhez viszonyítva $(\mathrm{P} \leq 0,05)$

aktivitást pedig a 0,2\%-os NaCl-értéknél mértük. A dehidrogenáz- és a katalázaktivitás még 0,4\%-os NaCl-koncentráció mellett sem csökkent szignifikáns mértékben. Mindkét enzim aktivitása igazolhatóan csökkent azonban a kontrollhoz viszonyítva $0,8 \%$-os NaCl-koncentráció mellett.

Az eredmények szerint az oxidoreduktázokra a talaj növekvő sótartalma különbözen hat, jelezve, hogy a mikroorganizmusok sókoncentráció növekedésére adott fiziológiai válaszreakciói különböznek.

A N-körforgásban szerepet játszó hidrolitikus enzimek, a proteáz és az ureáz aktivitásának maximális értékét egyaránt $0,2 \%$-os koncentráció mellett mértük. Ezen enzimek aktivitása még $0,4 \%$-os érték mellett is magasabb volt, mint a kontrollnö- 
vények rizoszférájában, a 0,8\%-os értéknél azonban a proteázaktivitás szignifikánsan csökkent, míg az ureáz aktivitása igazolhatóan nem változott.

A foszfatáz és a $\beta$-glükozidáz rizoszférában mért aktivitásának változása a sókezelés hatására eltért az előző négy enzimétől: a sókoncentráció növekedésével ez utóbbiak fokozatosan csökkentek. A foszfatáz aktivitása a talajhoz adott NaCladagok emelésével nagyobb mértékben csökkent, mint a $\beta$-glükozidázé. Ez az aktivitáscsökkenés $0,2 \mathrm{~m} / \mathrm{m} \%$-os sókoncentrációnál és afölött szignifikáns volt $(\mathrm{P} \leq$ $0,05)$.

Az enzimaktivitásokat a vizsgált babfajták szerint értékelve megállapítható, hogy mindegyik enzim esetében rendre a barna-, fehér- és gyöngybab csökkenő sorrend állítható fel, ami arra utal, hogy a különböző fajták fiziológiai állapota a sóstressz következtében eltérő, fajtára jellemző mértékben változik meg.

\section{Az eredmények megvitatása}

A világ termőterületeinek mintegy 7\%-a sós, helyenként szikes talaj (SZABOLCS, 1994), ezért az egyes köztermesztésben lévő növényfajok és -fajták sótoleranciájának, valamint a só hatására gyökérrendszerükben végbemenő biológiai változások tisztázása a hatékony mezőgazdasági termelés nem elhanyagolható kérdése. A bab a talajok sótartalmára leginkább érzékeny növényfajok egyike. ABBAS és munkatársai (1991) szerint a talaj növekvő sókoncentrációja gátolja a babnövény növekedését, melyet vizsgálataink is alátámasztanak, hiszen a só $0,4 \mathrm{~m} / \mathrm{m} \%$ koncentrációban, illetve a fölött szignifikánsan csökkentette a növények relatív száraztömegét a kontrollhoz képest.

Már a hatvanas években (BERNSTEIN \& OGATA, 1966) leírták, hogy a só által elöidézett környezeti stressz a pillangós növények N-kötésének, illetve gümöképzésének mértékét is hátrányosan befolyásolja. Ezt jelen vizsgálatainkkal is igazoltunk, amennyiben a gümőképzés már $0,2 \mathrm{~m} / \mathrm{m} \%$ koncentráció fölött észrevehetően csökkent, majd - egyre nagyobb koncentrációkat alkalmazva - teljesen meg is szünt. ZAITER és MAHFOUZ (1993) is ezzel megegyező eredményekre jutott.

A bab három vizsgált fajtájának gyökérkörnyezetében a sókezelés hatására szignifikánsan megváltozott a fluoreszkáló Pseudomonas baktériumok csíraszáma. Az adatok a sókoncentrációval párhuzamosan egy átmeneti emelkedést mutattak, majd a legnagyobb NaCl-dózis hatására a kontrollnak megfelelő szintre csökkentek. Ez a tendencia a szikes talajok eltérő sótartalmánál tapasztalt mikrobaszám-értékekkel megfelelő egyezést mutat természetes körülmények között is (FüZY et al., 2003).

Ez a változás többféleképpen magyarázható. A talaj megnövekedett sótartalma a negatív kemotaxis révén a Pseudomonasokat a kiegyenlítettebb környezetet jelentő rizoszférába irányítja, így azok ott nagyobb számban jelenhetnek meg. Ehhez kapcsolódóan ellentmondó adatokat közöl MATSUGUCHI és SAKAI (1995), akik tenyészedény-kísérletben a gyökérmentes talaj Gram-negatív baktériumok csíraszámában a sókezelés hatására nem találtak eltérést, a fluoreszkáló Pseudomonasok populációja ugyanakkor gyökérhatás nélkül is nött. Korábbi adatok alapján is (BIRÓ 
et al., 2002; FÜZY et al., 2003) feltételezzük tehát, hogy a só hatása a különféle baktériumcsoportok számának alakulásánál nem azonos mértékben jelentkezik. Az egyes, sóra érzékeny baktériumcsoportok háttérbe szorulása által a sótoleráns fajok a szabadon maradt ökológiai tér benépesítése révén is felszaporodhatnak. Ehhez hasonló mechanizmus útján is növekedhetett a fluoreszkáló Pseudomonasok csíraszáma az általunk vizsgált babfajták rizoszférájában a sókezelés hatására. MATSUGUCHI és SAKAI (1995) spenótnövények rizoszférájában a Gram-negatív populáció gyarapodását tapasztalták, de a fluorescens-putida típusú Pseudomonasok számában nem találtak változást. Ezt a tényt a különböző növényfajok eltérő rizoszférája (ISMAIL, 2003), illetve annak mikrobiális összetétele magyarázhatja, ami a kezdeti különbségek után térben és időben, illetve az egyéb kezelési vagy klimatikus viszonyoktól erősen függve (SZABÓ, 1992) dinamikusan változik.

A talaj sótartalmának megváltozása miatt módosuló mikroorganizmus-közösség összetételének változása azért is érdemel figyelmet, mert más, a sóra kevésbé érzékeny mikrobák számának és aktivitásának változását is okozhatja (GARCIA \& HERNANDEZ, 1996). A Gram-negatív baktériumok - köztük főként a Pseudomonas nemzetség tagjai - pl. jelentősen gátolhatják a Trichoderma gombák talajban való megtelepedését (NAÁR et al., 1997, 1999). E gombák közismert antagonistaként képesek meggátolni a talajlakó kórokozó gombák elszaporodását (NAÁR \& KECSKÉS, 1998), így a sótartalom növekedése akár a Pseudomonasokkal szemben toleráns fitopatogén gombák elszaporodását is eredményezheti.

A talaj sóval történt kezelésének hatására szignifikánsan megváltozott mind a hat vizsgált enzim aktivitása, ennek mértéke ugyanakkor nem azonos módon nyilvánult meg. A dehidrogenáz, a kataláz, a proteáz és az ureáz enzimek aktivitása a fluoreszkáló Pseudomonasok csíraszámának változásához hasonló tendenciát mutatott, míg a foszfatáz- és a $\beta$-glükozidáz-aktivitás már a legkisebb NaCl-dózis hatására is statisztikailag jelentős mértékben csökkent. Ez arra utal, hogy az első négy enzim aktivitásának növekedésében fontos szerepet játszhatott a Pseudomonasok számának növekedése, míg a foszfatáz- és a $\beta$-glükozidáz-aktivitás csökkenését a sóra érzékeny baktériumok visszaszorulása okozhatta.

FRANKENBERGER és BINGHAM (1982) kimutatta a sótartalom növekedésének különböző enzimek tevékenységére kifejtett gátló hatását, a jelenleg alkalmazott koncentráció azonban ennél kisebb volt, így feltételezhető, hogy a talaj NaClkezelése nem közvetlenül az enzimfehérjék aktivitását, hanem az azokat termelö mikrobaközösség összetételét befolyásolta, ennél fogva közvetett hatása volt kimutatható. Ily módon e munkával is igazoltuk, hogy a növényi rizoszféra kitenyészthető mikrobiális, valamint enzimaktivitása a környezet megváltozásának érzékeny jelzője lehet.

\section{Összefoglalás}

Üvegházi körülmények között, a Gödöllői-dombságból származó Ramann-féle barna erdőtalajon (Dystri-Chromic Cambisol; WRB, 1998) nevelt étkezési szárazbab (Phaseolus vulgaris L.) növény három, Magyarország eltérő ökológiai adottsá- 
gú területein is biztonsággal termeszthető, azonos tenyészidejü fajtája (Diana, Albamax és Perle) rizoszférájának $\mathrm{NaCl}$-kezelés hatására bekövetkezö változását követtük nyomon. Megvizsgáltuk a különbözö sókoncentrációknak $(0,0,2,0,4,0,6$ és 0,8 tömegszázalék) a baktériumnépesség összetételére és a különbözö talajenzimek aktivitására gyakorolt hatását.

Megállapítottuk, hogy a talaj sótartalma közvetlenül befolyásolta a rizoszférában található fluoreszkáló Pseudomonasok csíraszámát. A legsürübb populáció a 0,2\% NaCl-ot tartalmazó talajban jött létre, ahol a fluoreszkáló Pseudomonasok között a Pseudomonas putida és a $P$. fluorescens fordultak elő a legnagyobb számban. A Pseudomonasok ily módon jól tolerálják a nagy NaCl-koncentrációt a talajban, tehát gyökérkolonizáló tevékenységet képesek kifejteni erősen sós talajban is.

A talaj sóval történt kezelésének hatására szignifikánsan megváltozott mind a hat vizsgált enzim aktivitása, ennek mértéke ugyanakkor nem azonos módon nyilvánult meg. A sókoncentráció növelésével kezdetben (a $0,2-0,4 \%$-os tartományban) jelentősen növekedett a dehidrogenáz, kataláz, és ureáz enzimek aktivitása a barnabab rizoszférájában, míg a többi fajtáéban nem. A proteáz enzimek aktivitásának maximuma a $0,1-0,2 \% \mathrm{NaCl}$-koncentráció tartományba esett mindhárom vizsgált fajta esetében. A 0,4\%-nál magasabb koncentrációkban a kontrollhoz hasonló mértéküre csökkent mind a dehidrogenáz és a kataláz aktivitása (a többi enzimé szignifikánsan még kisebb volt), és a baktériumok száma is. A foszfatáz- és a $\beta$ glükozidáz-aktivitás viszont már a legkisebb $\mathrm{NaCl}$-adag következtében jelentősen csökkent a kontrollhoz viszonyítva, illetve, annál mindvégig szignifikánsan kisebb volt.

Feltételezésünk szerint az enzimaktivitások változását is a mikrobióta összetételének a sókezelés hatására bekövetkező változása okozta.

Kulcsszavak: babfajták, fluoreszkáló Pseudomonas populáció, NaCl-oldat, rizoszféra, talajenzimek aktivitása

\section{Irodalom}

AbBas, M. A., Younis, M. E. \& ShUKRY, W. M., 1991. Plant growth, metabolism and adaptation in relation to stress conditions. XIV. Effect of salinity on the internal solute concentrations in Phaseolus vulgaris. J. Plant Physiol. 138. 722-727.

ANTAL, M. \& ANTON, A., 1986. Comparative studies on saccharase activity of different Hungarian soils. Zbl. Mikrobiol. 141. 495-501.

ANTON, A. et al., 1994. Effect of environmental factors and Mn, Zn, Cu trace elements on the soil phospho-monoesterase and amidase activities. Application of DISITOBI model. Acta Biol. Hung. 45. 39-50.

BERNSTEIN, L. \& OGATA, G., 1966. Effect of salinity on nodulation, nitrogen fixation and growth of soybean and alfalfa. Agron. J. 58. 201-203.

BIRÓ, B., VILláNYI, I. \& KÖVES-PÉCHY, K., 2002. Abundance and adaptation level of some soil microbes in salt-affected soils. Agrokémia és Talajtan. 50.99-106. 
BIRÓ, B. et al., 1998. Specific replant disease reduced by PGPR rhizobacterium on apple seedlings. Acta Horticult. 477. 75-81.

DASH, M. \& PANDA, S. K., 2001. Salt stress induced changes in growth and enzyme activities in germinating Phaseolus mungo seeds. Biol. Plantar. 44. 587-589.

Frankenberger, W. T. \& Bingham, F. T., 1982. Influence of salinity on soil enzyme activities. Soil Sci. Soc. Am. J. 46. 1173-1177.

FÜZY A., BIRÓ B. \& TÓTH T., 2003. Növény-mikroba kölcsönhatások és néhány talajtulajdonság közötti összefüggés hazai szikeseken. Természetvédelmi Közlemények. 10. 64-69.

GARCÍA, C. \& HERNÁNDEZ, T., 1996. Influence of salinity on the biological and biochemical activity of a Calciorthid soil. Plant and Soil. 178. 255-263.

GARCíA, C. et al., 1993. The dehydrogenase activity of soil as an ecological marker in processes of perturbed system regeneration. In: Proc. XI. International Symposium of Environmental Biogeochemistry, Salamanca, Spain. (ED.: GALlardo, G. F.) 89-100.

ISMAIL, A. M., 2003. Effect of salinity on the physiological responses of selected lines/variety of wheat. Acta Agron. Hung. 51. 1-9.

KHALIF, A. A. et al., 2004. Enzimaktivitások és a fluoreszkáló pszeudomonasz csíraszámok változása a fehér lóhere (Trifolium repens L.) rizoszférájában sókezelés $(\mathrm{NaCl})$ hatására. Agrokémia és Talajtan. 53. 367-376.

KING, E. O., WARD, M. K. \& RANEY, P. E., 1954. Two simple media for the demonstration of fycocianin and fluorescin. J. Lab. Clin. Med. 44. 301-306.

Masciandaro, G., Ceccanti, B. \& Garacia, C., 1994. Anaerobic digestion of straw and piggery waste waters. II. Optimalization of the process. Agrochimica. 38. 195-203.

MATSUGUCHI, T. \& SAKAI, M., 1995. Influence of soil salinity on the populations and composition of fluorescent pseudomonads in plant rhizosphere. Soil Sci. Plant Nutr. 41. 497-504.

MiKANOVÁ, O. et al., 2001. Influence of heavy metal pollution on some biological parameters in the alluvium of the Litavka river. Rostlinná Výroba. 47. 117-122.

NAÁR, Z. \& KECSKÉS, M., 1998. Factors influencing the competitive saprophytic ability of Trichoderma spp. Microbiological Research. 153. 1-11.

NAÁR, Z., NEMES, M. \& KECSKÉS, M., 1999. The role of soil microbiota during colonization of different soil types by Trichoderma fungi. Acta Microbiol. Immunol. Hung. 46. 212 213.

NAÁR, Z. et al., 1997. Colonization of Trichoderma strains in different soil types affected by microbicides. In: Proc. International Regional Seminar Transcarp. Reg.. Envir. Prot., May 13-16, 1997, Uzhgorod, Ukraine. 22-27.

NANNIPIERI, P. et al., 1980. Extraction of phosphatase, urease, protease, organic carbon and nitrogen from soil. Soil Sci. Soc. Am. J. 44. 1011-1016.

NAUTIYAL, C. S. \& DiON, P., 1990. Characterization of opine-utilizing microflora associated with samples of soil and plants. Appl. Environ. Microbiol. 6. 2576-2579.

SzABÓ I. M., 1992. Az általános talajtan biológiai alapjai. Mezőgazdasági Kiadó. Budapest.

SzABOLCS, I., 1994. Soils and salinization. In: Handbook of Plant and Crop Stress. (Ed.: PeSSARAKALI, M.) 3-11. Marcel Dekker. New York.

SzEGI J., 1979. Talajmikrobiológiai vizsgálati módszerek. Mezőgazdasági Kiadó. Budapest. 
Tabatabai, M. A., 1982. Soil enzymes. In: Methods of Soil Analysis. Part 2. (Eds.: PaGe, A. L., Miller, R. H. \& KeENEY, D. R.) 903-947. American Society of Agronomy-Soil Science Society of America. Madison, WI.

TABATABAi, M. A. \& BREMNER, J. M., 1969. Use of P-nitrophenol phosphate in assay of soil phosphatase activity. Soil. Biol. Biochem. 1. 301-307.

TABATABAi, M. A. \& BREMnER, J. M., 1970. Factors affecting soil anyl-sulphate activity. Soil Sci. Soc. Amer. Proc. 34. 427-429.

World SOIL RESOURCES REPORTS 84, 1998. World Reference Base for Soil Resources. FAO, ISRIC and ISSS-AISS-IBG. Rome.

ZAITER, H. \& MAHFOUZ, B., 1993. Salinity effect on root and shoot characteristics of common and tepary beans evaluated under hydroponic solution and sand culture. J. Plant Nutr. 16. 1569-1592.

Érkezett: 2005. március 21. 


\title{
Changes in Microbe Number and Enzyme Activity in the Rhizosphere of Dry Bean Varieties (Phaseolus vulgaris L.) in Response to Salt Stress
}

\author{
${ }^{1}$ KHALIF A. ABDOUSSALAM, ${ }^{1}$ ABDORHIM HAMED, ${ }^{1}$ BAYOUMI HAMUDA E. A. F. \\ HOSAM, ${ }^{2}$ B. OLDAL and ${ }^{1} \mathrm{M}$. KECSKÉS \\ ${ }^{1}$ Postgraduate School of Environmental Studies, Szent István University, Gödöllö-Budapest and \\ ${ }^{2}$ Research Institute for Soil Science and Agricultural Chemistry of the Hungarian Academy of \\ Sciences, Budapest
}

\begin{abstract}
Summary
Changes caused by salt treatment in the rhizosphere of three dry edible bean (Phaseolus vulgaris L.) varieties with the same vegetation period (Diana, Albamax and Perle), which can be reliably grown under the diverse ecological conditions in various regions of Hungary, were examined under greenhouse conditions on a Ramann brown forest soil. The effect of various $\mathrm{NaCl}$ concentrations $(0,0.2,0.4,0.6$ and $0.8 \mathrm{~m} / \mathrm{m} \%)$ was studied on the composition of the bacterium population and on the activity of various soil enzymes.

The soil salt content was found to have a direct influence on the germ number of the fluorescing Pseudomonas bacteria found in the rhizosphere. The densest population was observed in soil containing $0.2 \% \mathrm{NaCl}$, where Pseudomonas putida and P. fluorescens occurred in the largest numbers. This indicates that Pseudomonas species have good tolerance of high $\mathrm{NaCl}$ concentrations in the soil, allowing them to colonise roots even in soil having high salt content. As the salt concentration rose $(0.2-0.4 \%)$ there was an increase in the activity of the dehydrogenase, catalase and urease enzymes in the rhizosphere of the brown bean variety, but not in that of the other varieties. The maximum protease activity was observed in the $0.1-0.2 \% \mathrm{NaCl}$ concentration range for all three varieties. At concentrations higher than $0.4 \%$ the activity of dehydrogenase and catalase dropped to the control level (that of the other enzymes was significantly even lower), and this was also true of the number of bacteria. The phosphatase and $\beta$ glucosidase activity declined substantially compared with the control even at the lowest $\mathrm{NaCl}$ rate and remained significantly lower than the control throughout the experiment. The change in enzyme activity is thought to have been induced by the change in the microbe composition in response to salt treatment.

Table 1. Changes in the microbe number in the rhizosphere of bean varieties treated with various concentrations of $\mathrm{NaCl}$ solution $(\mathrm{m} / \mathrm{m} \%)$. (1) Microbe groups. a) bacteria; b) aerobic spore-forming bacteria; c) Actinomycetes; d) fungi. (2) Bean varieties. (3) $\mathrm{NaCl}$ treatment $(\mathrm{m} / \mathrm{m} \%)$. (4) LSD. Note: *Significantly different from the control value $(\mathrm{P} \leq 0.05)$.

Table 2. Bacterium populations in the rhizosphere of various bean varieties after 50 days of growth in the greenhouse in Ramann brown forest soil from Gödöllő. (1) Composition of the dominant bacterium population in the rhizosphere. a) Gram negative; b) rod-shaped; c) fluorescing Pseudomonas; d) Gram positive. (2) Ratio, \%.

Table 3. Population of fluorescing Pseudomonas in the rhizosphere of various bean varieties in response to rising salt concentrations. (1) $\mathrm{NaCl}$ treatment (m/m\%). a) LSD. (2) No. of fluorescing Pseudomonas. Note: see Table 1.
\end{abstract}


Table 4. Changes in the number of root nodules in the rhizosphere of various bean varieties in response to rising salt concentrations. (1): see Table 3. (2) No. of root nodules.

Table 5. Changes in the relative dry mass of the plants of various bean varieties in response to rising salt concentrations. (1): see Table 3.

Table 6. Effect of soil treatment with $\mathrm{NaCl}$ on enzyme activity in the rhizosphere of various bean varieties. (1) Enzymes and units. a) Dehydrogenase; b) catalase; c) protease; d) urease; e) phosphatase; f) $\beta$-glucosidase. (2) Bean varieties. (3) Enzyme activity at various $\mathrm{NaCl}$ concentrations (mean of three measurements). $\mathrm{SzD}=\mathrm{LSD}$. 